\title{
PEMBUATAN CUCI TANGAN SEDERHANA PADA MASYARAKAT DAERAH ZONA MERAH SEBAGAI LANGKAH PENCEGAHAN PENYEBARAN COVID-19
}

\author{
Fatin Hanifa, Annisa Hidaya Rahmah, Fadila Damayana, Hafidh Triandha Khan, \\ Ivan Fadilah, Mahsa Dwi Lestari, Yuni Sartika \\ Universitas Abdurrab, Pekanbaru, Indonesia \\ fatin.hanifa@univrab.ac.id
}

\begin{abstract}
COVID-19 has a big impact on Pekanbaru's society, especially in the Tampan sub-district. Tampan sub-district is an area with the most positive COVID-19 cases and less welfare in socio-economic conditions. it become our concern for carrying out community service in that district. The problem was found as the lack of information on how to deal with pandemic conditions. This condition affects public awareness to comply with health protocols. This community service is expected to be able to ease the burden on the underprivileged community to help people adapt to new habits to comply with health protocols. The form of work program carried out is to provide a simple sink made of used buckets and hand soap, distribute free masks to the community where the service is located, and making information through social media as a form of education-related to pandemic conditions. The work program of the thirtytwo group from Abdurab University community service ran smoothly and effectively. This is due to the support and appreciation from both the urban village and the head of RT 1 RW 1, Delima village. The service program carried out includes the Health and Scientific fields. This program in the health sector includes the distribution of masks, as well as the manufacture of sinks and soap. As for programs in the scientific field, namely counseling and outreach to the public about how to maintain health during the Covid-19 pandemic through a bold educational program on social media on Instagram @ kkn32.univrab.
\end{abstract}

Keywords: Prevention; COVID-19; sink; simple

\begin{abstract}
Abstrak
COVID-19 memberikan dampak nyata terhadap masyarakat Pekanbaru terutama kecamatan Tampan. Kecamatan tampan sebagai daerah dengan tingkat kasus positif terbanyak serta kondisi sosial ekonomi yang kurang sejahtera menjadi perhatian kami untuk melakukan pengabdian masyarakat di kecamatan tersebut. Permasalahan yang ditemukan adalah kurangnya informasi terkait bagaimana cara menghadapi kondisi pandemik. Kondisi ini mempengaruhi kesadaran masyarakat untuk mematuhi protokol kesehatan. Pengabdian ini diharapkan mampu meringankan beban masyarakat yang kurang mampu hingga membantu masyarakat untuk beradaptasi dengan kebiasaan baru yaitu mematuhi protokol kesehatan. Adapun bentuk program kerja yang dilakukan ialah pengadaan fasilitas cuci tangan sederhana yang terbuat dari ember bekas dan sabun cuci tangan, distribusi masker gratis ke masyarakat lokasi tempat pengabdian, serta membuat informasi melalui sosial media sebagai bentuk edukasi terkait penyesuaian kondisi pandemik. Program kerja Kuliah Kerja Nyata kelompok 32 dari Universitas Abdurab berjalan dengan lancar dan efektif. Hal ini dikarenakan adanya dukungan dan apresiasi baik dari kelurahan dan ketua RT 1 RW 1 kelurahan Delima. Program pengabdian yang dilakukan mencakup bidang Kesehatan dan bidang Keilmuan. Program bidang Kesehatan ini antara lain pembagian masker, serta pembuatan bak cuci tangan dan sabunnya. Sedangkan untuk program dalam bidang Keilmuan yaitu Penyuluhan dan sosialisasi kepada masyakat mengenai bagaimana menjaga kesehatan selama pandemi Covid-19 lewat program edukasi daring di sosial media instragram @kkn32.univrab.
\end{abstract}

Kata Kunci: Pencegahan; COVID-19; bak cuci tangan; sederhana

Submitted: 2020-09-19 Revised: $2020-10-04$ Accepted: $2020-10-16$ 


\section{Pendahuluan}

COVID-19 atau Virus Corona merupakan penyakit baru yang penyebarannya sangat cepat dan telah menjadi pandemi di Indonesia saat ini (Susilo, et al, 2020; Syafrida \& Hartati, 2020). Berdasarkan hasil penelitian literatur yang dilakukan oleh Susilo et al (2020) menunjukkan bahwa penyakit yang disebabkan oleh COVID-19 sebaiknya perlu diwaspadai dan tidak abaikan. Hal ini disebabkan karena penularan virus ini relatif cepat dan mampu menyebabkan kematian yang tinggi. Manusia ditemukan sebagai sumber penyebaran utama dalam penyebaran virus ini. Penyebaran dari manusia ke manusia ini melalui cairan (droplet) yang ikut keluar pada saat batuk atau bersin (Han \& Yang, 2020).

Beberapa kasus yang ditemukan bahwa korban penyebaran COVID-19 umumnya memiliki kontak langsung dan intens dengan pasien COVID-19 (Bai, et al, 2020). Lebih lanjut WHO (2020) menjelaskan berdasarkan bukti bahwa penyebaran COVID-19 melalui air liur, sekresi saluran pernapasan atau melalui cairan saluran nafas yang terjadi ketika melakukan kontak langsung, tidak langsung maupun intens dengan orang yang terinfeksi COVID-19. Adapun kegiatan yang memungkinkan individu terpapar droplet ialah ketika seseorang berbicara, bersin, batuk, atau menyanyi.

Susilo et.al (2020) belum menemukan treatment yang mampu mengurangi penyebarannya. Namun, menurut WHO dan Kementerian kesehatan terdapat beberapa usaha yang bisa dilakukan untuk mencegah penyebaran COVID-19 ialah isolasi, deteksi dini serta melakukan proteksi dasar(WHO, 2020; KEMENKES, 2020).

Jumlah kasus positif COVID-19 di Indonesia per 11 September 2020 menjadi 210.940, pasien sembuh 150.217 serta pasien meninggal 8.544 orang (health.detik.com). Sedangkan data penyebaran COVID-19 di provinsi Riau per tanggal 11 September 2020 menunjukkan 3343 orang terkonfirmasi COVID-19, 59 orang meninggal dunia dengan 22462 orang diduga terkena COVID-19. Untuk kota Pekanbaru terdapat 2082 orang terkonfirmasi COVID-19 dan 45 orang meninggal dunia (corona.riau.go.id). Berdasarkan update terbaru covid-19 tanggal 11 September 2020 didapatkan bahwa Kecamatan Tampan menempati urutan tertinggi diseluruh kecataman yang ada di Kota Pekanbaru yaitu sebanyak 178 konfirmasi kasus covid-19 (ppc-19.pekanbaru.go.id).

Kondisi pandemi menjadi tanggung jawab semua masyarakat yang ada di daerah tersebut. Peran warga menjadi penting sebagai support system terdekat. Kehadiran orang lain yang dapat membantu masalah, memberika semangat dan penerimaan serta perhatian mampu meningkatkan kesejahteraan orang lain (Sarafino \& Smith, 2011), Peran penting ini juga sesuai dengan Tri Dharma Perguruan Tinggi yang ketiga yaitu pengabdian kepada masyarakat (Wibawa, 2017), maka tanggung jawab mahasiswa setelah mendapatkan ilmu dari kampus adalah mentransfer, menginformasikan dan mengaplikasikan ilmunya kepada masyarakat (undang-undang nomor 20, 2003). Dari hasil pengaplikasian itu seorang mahasiswa dapat diukur mengenai kesiapan dan kemampuannya sebelum akhirnya menjadi bagian dari masyarakat luas. Beranjak dari hal itu maka diadakanlah program KKN sebagai implementasi dari pengabdian kepada masyarakat dan pengaplikasian ketrampilan dan ilmu pengetahuan yang dimiliki kepada masyarakat. 
Kuliah Kerja Nyata (KKN) merupakan salah satu program perkuliahan yang wajib ditempuh oleh mahasiswa. KKN dilaksanakan di masyarakat dan langsung berinteraksi dengan masyarakat. Hal ini bertujuan untuk mengembangkan daerah sekitar melalui berbagai program yang dirancang. Sehingga dari kedua belah pihak yaitu mahasiswa dan masyarakat dapat saling belajar satu sama lain. Dalam proses pembelajaran ini mahasiswa diharapkan dapat menghubungkan konsep-konsep perkuliahan dengan kehidupan nyata yang ada di masyarakat. Kegiatan Kuliah Kerja Nyata adalah suatu bentuk pendidikan dengan cara memberikan pengalaman empiris kepada mahasiswa untuk hidup di tengah-tengah masyarakat di luar kampus, dan secara langsung megajarkan kepada mahasiswa cara identifikasi masalah-masalah sosial kerakyatan. Kuliah Kerja Nyata secara langsung akan menunjukan keterkaitan langsung antara dunia pendidikan dan upaya perwujudan kesejahteraan masyarakat.

Kuliah Kerja Nyata merupakan bagian dari program pengabdian kepada masyarakat yang menjadi kewajiban akademik bagi setiap Mahasiswa Universitas Abdurrab Pekanbaru Semester 6. Pada tahun ini program KKN dilakukan penuh secara daring, namun diharapkan mahasiswa tetap melaksanakan program pemberdayaan kepada masyarakat berbasis pengabdian masyarakat dalam mencegah penyebaran Covid19. Berdasarkan hasil survei yang dilakukan oleh LPPM dan juga hasil koordinasi dengan pihak pemerintah setempat maka KKN pada tahun 2020 ini diselenggarakan di wilayah yang ada di Provinsi Riau dengan Skema pelaksanaan Kuliah Kerja Nyata yakni: "KKN Terintegrasi" dan "KKN Balek Kampung" dengan pertimbangan karena kondisi pandemi Covid-19. Melalui Kuliah Kerja Nyata (Kukerta) balek kampung ini, target kegiatan pengabdian mahasiswa dari kelompok 32 yaitu di daerah Kelurahan Delima kecamatan Tampan.

Kecamatan Tampan ini terbentuk yang berdasarkan PP No. 19 Tahun 1987 yang diatas tadi. Pada tahun 2003 Pemerintah Kata Pekanbaru mengeluarkan Perda No. 03 Tahun 2003, Wilayah Kecamatan Tampan dimekarkan menjadi 2 Kecamatan dengan batas-batas sebelah Timur berbatasan dengan Kecamatan Marpoyan Damai (Kota Pekanbaru), sebelah Barat berbatasan dengan Kecamatan Tambang (Kabupaten Kampar), sebelah Utara berbatasan dengan Kecamatan Payung Sekaki (Kota Pekanbaru), dan sebelah Selatan berbatasan dengan Kecamatan Tambang (Kabupaten Kampar).

Wilayah Kec. Tampan pada saat ini adalah $+65 \mathrm{~km}^{2}$ dengan empat Kelurahan di dalamnya yaitu kelurahan Simpang Baru, kelurahan Tuah Karya, kelurahan Sidomulyo Barat, dan kelurahan Delima. Berdasarkan letak geografis Kelurahan Delima terkhusus di wilayah RT.1/ RW.1 mempunyai letak yang sangat strategis dan memiliki sarana dan pra sarana yang memadai juga prospek untuk lebih berkembang. Masyarakat Kelurahan Delima Khususnya RT.01 RW.01 bila ditinjau dari umur dan jenis kelamin, umur masyarakat yang menduduki RT.01 RW.01 bervariasi mulai dari bayi,anakanak,dewasa,orang tua serta untuk jenis kelamin didominasi oleh kaum perempuan. Pekerjaan masyarakat didominasi oleh pedagang dan pegawai kantoran. Masyarakat juga merupakan warga yang tanggap dan memiliki jiwa sosial yang tinggi.

Namun, pertumbuhan ekonomi yang kurang merata padahal sudah berada di tengah kota, akan tetapi masih banyak masyarakat yang kurang mampu dikarenakan ada beberapa kepala keluarga yang tidak mempunyai pekerjaan tetap. Ditambah dampak pandemi covid-19 ini semakin banyak masyarakat yang terkena dampaknya mulai dari 
diberhentikan ditempat kerja, pengurangan hak kerja, bahkan dari segi ekonomi kesulitan dalam memenuhi kebutuhan sehari-hari. Meskipun Pemerintah Kota Pekanbaru sudah berusaha semaksimal mungkin untuk mencari solusi memperbaiki ekonomi di saat kondisi pandemi ini, namun hal tersebut masih belum bisa terselesaikan karena begitu padatnya masyarakat kota bengkalis yang harus dibantu perekonomiannya seperti salah satunya di kelurahan Delima.

Adapun permasalahan yang kami temukan sebagai berikut:

a. Kurangnya edukasi mengenai Covid-19 dan menjalankan kehidupan terhadap tatanan pandemic yang terjadi;

b. Kesadaran masyarakat yang minim untuk mematuhi protokol kesehatan;

c. Masih banyak masyarakat yang berkumpul dan melakukan kegiatan di tengah keramaian;

d. Kurangnya seminar atau pemberitahuan secara halus kepada masyarakat untuk menunjukkan praktik adaptasi kebiasaan baru;

e. Dengan adanya pandemi Covid-19 banyak pekerja yang dirumahkan dengan waktu yang tidak dapat ditentukan membuat kesulitan ekonomi dan berdampak terhadap kemerosotan ekonomi akibat pandemic Covid-19.

Harapan kami, dengan hadirnya Mahasiswa Universitas Abdurrab Pekanbaru dalam Kukerta Balek Kampung ini dapat meringankan beban masyarakat yang kurang mampu, dan harapannya masyarakat juga dapat memperoleh ilmu dan wawasan terkait pandemi Covid-19 serta mulai membiasakan diri dengan adaptasi kebiasaan baru yaitu mematuhi protokol kesehatan sesuai anjuran dari WHO.

Berdasarkan potensi serta masalah yang kami temukan dan paparkan, Kami memilih lokasi yang cukup strategis untuk tempat prakter Kukerja di wilayah Kec. Tampan khususnya Kota Pekanbaru yang mana terdapat banyak pemukiman masyarakat, masih banyak ditemukan masyarakat kurang mampu yang butuh diberi pembinaan serta perhatian baik itu secara SDM maupun bantuan ekonomi..

\section{Metode}

Pelaksanaan Kuliah Kerja Nyata (KKN) dilakukan selama dua minggu pada tanggal 24 Agustus 2020 s.d. 12 September 2020 yang bertempat di RT. 1 RW. 1 Kel. Delima, Kec. Tampan, Kota Pekanbaru, Riau. Penyelenggaraan dari kegiatan ini adalah Mahasiswa KKN Kelompok 32 Universitas Abdurrab Pekanbaru yang terdiri dari mahasiswa angkatan 2016 dan tahun 2017. Adapun sumber dana dari program kerja dan kegiatan yang dilaksanakan adalah dengan dana pribadi yang dikeluarkan oleh masing-masing mahasiswa yang tergabung dalam Kelompok 32. Perkiraan Dana yang dibutuhkan dari kegiatan ini sebesar Rp. 400.000,-.

Pelaksanaan kegiatan dilakukan dengan tetap mengikuti arahan dari protokol kesehatan seperti menggunakan masker, mencuci tangan dan tetap menjaga jarak. Adapun kegiatan pelaksaan pengabdian ini terdiri dari tiga kegiatan yaitu:

1. Pembuatan bak cuci tangan beserta sabun cuci tangan

2. Pembagian masker

3. Memberikan edukasi berupa gambar dan video edukasi melalui media sosial intagram kelompok 32. 


\section{Hasil dan Pembahasan}

Pencegahan COVID-19 cukup terbatas mengingat bahwa penyakit ini masih baru dan belum banyak penelitian yang membahas terkait penanganannya (Susilo, et al, 2020). Lebih lanjut disampaikan bahwa hal utama yang bisa dilakukan ialah memutus rantai penyebaran virus dengan isolasi, deteksi dini serta melakukan perlindungan umum (WHO, 2020; KEMENKES, 2020). Shang, Yang, Rao dan Rao (2020) menambahkan bahwa upaya yang sedang dilakukan untuk meningkatkan imunitas serta mencegah penyebaran virus ialah dengan mengembangkan vaksin. Kemudian upaya yang dapat dilakukan oleh individu yang pernah berkontak fisik dengan pasien positif COVID-19 ialah dengan deteksi dini dan isolasi dan berobat ke fasilitas kesehatan (WHO, 2020).

WHO juga telah membuat instrumen penilaian risiko bagi petugas kesehatan yang menangani pasien COVID-19 sebagai panduan rekomendasi tindakan lanjutan. Bagi kelompok risiko tinggi, direkomendasikan pemberhentian seluruh aktivitas yang berhubungan dengan pasien selama 14 hari, pemeriksaan infeksi SARS-CoV-2 dan isolasi. Pada kelompok risiko rendah, dihimbau melaksanakan pemantauan mandiri setiap harinya terhadap suhu dan gejala pernapasan selama 14 hari dan mencari bantuan jika keluhan memberat (WHO, 2020). Pada tingkat masyarakat, usaha mitigasi meliputi pembatasan berpergian dan kumpul massa pada acara besar (social distancing) (WHO,2020).

Rekomendasi WHO dalam menghadapi wabah COVID-19 adalah melakukan proteksi dasar, yang terdiri dari cuci tangan secara rutin dengan alkohol atau sabun dan air, menjaga jarak dengan seseorang yang memiliki gejala batuk atau bersin, melakukan etika batuk atau bersin, dan berobat ketika memiliki keluhan yang sesuai kategori suspek. Rekomendasi jarak yang harus dijaga adalah satu meter(WHO, 2020). Pasien rawat inap dengan kecurigaan COVID-19 juga harus diberi jarak minimal satu meter dari pasien lainnya, diberikan masker bedah, diajarkan etika batuk/bersin, dan diajarkan cuci tangan (WHO, 2020). Perilaku cuci tangan harus diterapkan oleh seluruh petugas kesehatan pada lima waktu, yaitu sebelum menyentuh pasien, sebelum melakukan prosedur, setelah terpajan cairan tubuh, setelah menyentuh pasien dan setelah menyentuh lingkungan pasien.

Air sering disebut sebagai pelarut universal, namun mencuci tangan dengan air saja tidak cukup untuk menghilangkan coronavirus karena virus tersebut merupakan virus RNA dengan selubung lipid bilayer (Riedel et al, 2019). Sabun mampu mengangkat dan mengurai senyawa hidrofobik seperti lemak atau minyak (Riedel et al, 2019) Selain menggunakan air dan sabun, etanol 62-71\% dapat mengurangi infektivitas virus (Kampf, Todt, Pfanser\& Steinmann, 2020). Oleh karena itu,membersihkan tangan dapat dilakukan dengan hand rub berbasis alkohol atau sabun dan air. Berbasis alcohol lebih dipilih ketika secara kasat mata tangan tidak kotor sedangkan sabun dipilih ketika tangan tampak kotor (WHO,2020). Selain itu penggunaan masker juga menjadi upaya penting untuk menghindari penyebaran COVID-19 bagi individu sehat.

Berdasarkan jurnal dan artikel tersebut, maka kami memilih pengadaan fasilitas cuci tangan dan sabun serta distribusi masker gratis sebagai bentuk pengabdian kepada masyarakat. Seluruh kegiatan pelaksanaan pengabdian di wilayah RT.1/RW.1 berjalan dengan lancer. Hal ini terlihat dari ketua RT yang mendukung penuh kegiatan Kukerta 
Abdurrab ini dan juga mengucapkan terima kasih kepada mahasiswa Kukerta Universitas Abdurrab karena telah turut membantu dalam membangkitkan kesadaran masyarakat Kota Pekanbaru terutama di wilayah RT.1/RW.1 Kelurahan Delima untuk selalu mengikuti arahan dari protokol kesehatan. Berikut pernjelasan program kerja KKN yang telah dilakukan seperti di tabel 1.

Tabel 1. Program Kerja KKN

\begin{tabular}{|c|c|c|c|c|}
\hline No & Program Kerja & Tujuan & Kegiatan & Rincian kegiatan \\
\hline 1 & $\begin{array}{l}\text { Menyediakan } \\
\text { fasilitas untuk } \\
\text { bak air cuci } \\
\text { tangan dan } \\
\text { sabunnya dan } \\
\text { dibagikan } \\
\text { secara gratis }\end{array}$ & $\begin{array}{l}\text { Agar masyarakat } \\
\text { bisa lebih peka } \\
\text { terhadap pentingnya } \\
\text { mencuci tangan } \\
\text { untuk menjaga } \\
\text { kebersihan pribadi } \\
\text { dan orang sesuai } \\
\text { dengan anjuran } \\
\text { WHO, }\end{array}$ & $\begin{array}{l}\text { Menyebarkan peletakan } \\
\text { fasilitas tempat pencuci } \\
\text { tangan disekitar tempat } \\
\text { keramaian di wilayah } \\
\text { RT.1/ RW.1 }\end{array}$ & $\begin{array}{l}\text { Fasilitas pencuci tangan dibuat } \\
\text { dengan ember bekas yang di } \\
\text { cat dan pembuatan sabun cuci } \\
\text { tangan untuk dibagikan di } \\
\text { daerah keramaian. Kegiatan ini } \\
\text { dilakukan secara berangsur- } \\
\text { angsur dimulai dari pukul } \\
10.00 \text { WIB hingga berakhir } \\
\text { pada pukul } 12.00 \text { WIB. }\end{array}$ \\
\hline 2 & $\begin{array}{l}\text { Pembagian } \\
\text { Masker }\end{array}$ & $\begin{array}{l}\text { Untuk meningkatkan } \\
\text { kesadaran } \\
\text { masyarakat guna } \\
\text { menjaga kesehatan } \\
\text { fisik serta untuk } \\
\text { mendapatkan } \\
\text { dukungan dari } \\
\text { masyarakat terkait } \\
\text { kegiatan yang kami } \\
\text { laksanakan }\end{array}$ & $\begin{array}{l}\text { Membagikan masker di } \\
\text { sekitar perumahan } \\
\text { yang berada di } \\
\text { kawasan RT.1/RW.1, } \\
\text { Kelurahan Delima, } \\
\text { Kecamatan Tampan, } \\
\text { Kota Pekanbaru. }\end{array}$ & $\begin{array}{l}\text { dilakukan dengan pembagian } \\
\text { di sekitar perumahan } \\
\text { RT.1/RW.1 Kelurahan Delima } \\
\text { dengan langsung didampingi } \\
\text { oleh Ketua RT.1 }\end{array}$ \\
\hline 3 & $\begin{array}{l}\text { Memberikan } \\
\text { edukasi via } \\
\text { social media }\end{array}$ & $\begin{array}{l}\text { Untuk memberikan } \\
\text { informasi kegiatan } \\
\text { yang mendidik ke } \\
\text { khalayak luas } \\
\text { melalui social media }\end{array}$ & $\begin{array}{l}\text { Memberikan informasi } \\
\text { bersifat edukatif } \\
\text { berbentuk Video dan } \\
\text { gambar di sosial media } \\
\text { KKN Universitas } \\
\text { Abdurrab Kelompok } 32 \\
\text { melalui media } \\
\text { instagram : } \\
\text { @kkn32.univrab }\end{array}$ & $\begin{array}{l}\text { Desain dan pengeditan } \\
\text { dilakukan oleh admin } \\
\text { instagram yaitu Annisa Hidaya } \\
\text { Rahmah yang juga merupakan } \\
\text { mahasiswa jurusan ilmu } \\
\text { komunikasi yang pembelajaran } \\
\text { jurusannya juga berhubungan } \\
\text { dengan pembuatan konten } \\
\text { media. }\end{array}$ \\
\hline
\end{tabular}

Berikut gambaran hasil program kerja KKN kelompok 32 berupa fasilitas cuci tangan dan sabun yang berasal dari ember bekas serta pembagian masker gratis ke warga RT 1 RW 1 kelurahan Delima kecamatan Tampan. Dapat dilihat pada gambar 1 dan 2. 


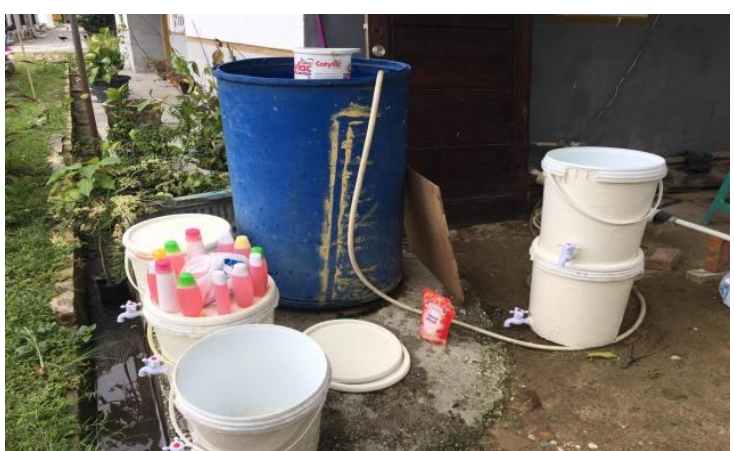

Gambar 1. Hasil pembuatan fasilitas cuci tangan dengan ember bekas

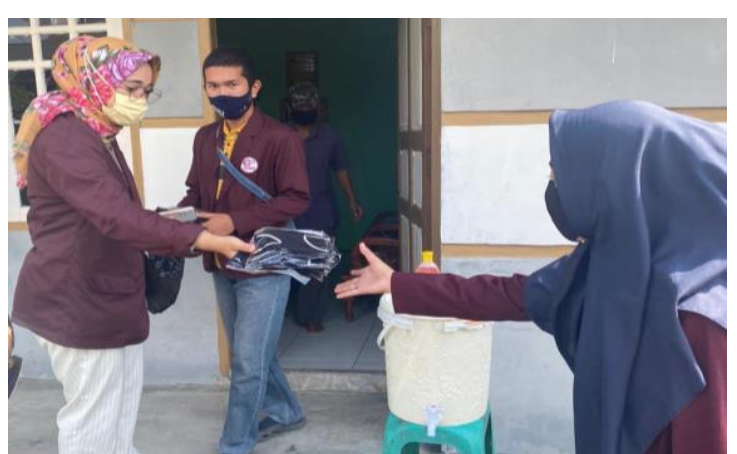

Gambar 2. Distribusi masker ke warga RT 1 RW 1

Dilihat dari segi sikap supportif masyarakat kami selaku peserta Kukerta ini mengalami kesulitan yaitu kurangnya kesadaran masyarakat terkait protokol kesehatan seperti menggunakan masker, mencuci tangan dan menjaga jarak dengan orang lain. Perlunya sosialisasi bagi masyarakat agar dapat selalu mengikuti prokol kesehatan agar pemutusan rantai penularan covid-19 dapat ditangani dengan cepat dan tidak menyebar luas ke semua orang. Masyarakat Kota Pekanbaru sudah mau menggunakan masker tetapi masih ada ditemukan masyarakat yang tidak menggunakan masker. Dalam pemantauan lokasi di Kelurahan Delima masih minimnya fasilitas masyarakat dalam adaptasi kondisi pandemi saat ini seperti salah satunya fasilitas cuci tangan di masingmasing RT dan RW.

\section{Kesimpulan}

Program KKN Universitas Abdurrab 2020 di Kelurahan Delima Pekanbaru yang telah dijalankan antara lain meliputi program bidang Kesehatan dan bidang Keilmuan. Program bidang Kesehatan ini antara lain pembagian masker, serta pembuatan bak cuci tangan dan sabunnya. Sedangkan untuk program dalam bidang Keilmuan yaitu penyuluhan dan sosialisasi kepada masyarakat mengenai bagaimana menjaga kesehatan selama pandemi Covid-19 lewat program edukasi daring di sosial media instragram @kkn32.univrab.

Keterbatasan waktu yang tersedia berdampak pada cakupan daerah yang dapat diintervensi. Selain itu, kondisi yang berstatus pandemi ini berpengaruh pada sosialisasi secara tatap muka yang dinilai kurang maksimal. Meski demikian, pelaksanaan kegiatan KKN ini berjalan efektif karena mahasiswa juga mendapatkan dukungan dari berbagai pihak yaitu dari Kelurahan Delima dan Ketua RT.1/RW.1 di Kelurahan tersebut.

Adapun saran yang diberikan untuk masyarat ialah isolasi mandiri: berdiam di dalam rumah sebanyak mungkin dan berusaha menghindari kontak dengan orang lain. Kemudian Physical distancing: dikenal juga sebagai social distancing, adalah upaya menjaga jarak fisik dari orang lain untuk mengurangi tingkat infeksi seperti dengan penutupan sekolah dan toko-toko. Selanjutnya saran yang kami berikan untuk pemerintah yaitu pemerintah dapat membantu memetakan kelompok masyakat dan lansia yang beresiko terinfeksi Covid-19. identifikasi orang-orang yang paling berisiko terdampak wabah ini. Kemudian Pemerintah juga dapat membantu mencarikan pekerjaan pada masyarakat yang dirumahkan atau di PHK akibat musibah Covid-19, atau memberikan 
bantuan dana pada masyarakat kurang mampu untuk kembali menstabilkan ekonomi masyarakat di tengah pandemi Covid-19.

\section{Daftar Pustaka}

Bai, Y., et al.(2020) Presumed Asymptomatic Carrier Transmission of COVID-19. JAMA, DOI: $10.1001 /$ jama.2020.2565

Direktorat Jenderal Pencegahan dan Pengendalian Penyakit. (2020). Pedoman Kesiapsiagaan Menghadapi Coronavirus Disease (COVID-19) Maret 2020. Jakarta: Kementerian Kesehatan Republik Indonesia

Han Y, Yang H. (2020). The transmission and diagnosis of 2019 novel coronavirus infection disease (COVID-19): A Chinese perspective. Journal of medical Virology.92, 639-644, DOI: 10.1002/jmv.25749

https://corona.riau.go.id/data-statistik/

https://health.detik.com/berita-detikhealth/d-5169070/update-corona-indonesia-11september-3737-kasus-baru-total-210940

https://ppc-19.pekanbaru.go.id/

Kampf, G., Todt, D., Pfaender, S., \& Steinmann, E. (2020). Persistence of coronaviruses on inanimate surfaces and their inactivation with biocidal agents. $J$ Hosp Infect. 104(3):246-51.

Kota Pekanbaru. (2003). Peraturan Daerah Kota Pekanbaru Nomor : 3 Tahun 2003 Tentang Pembentukan Kecamatan Marpoyan Damai, Kecamatan Tenayan Raya, Kecamatan Payung Sekaki Dan Kecamatan Rumbai Pesisir. Sekretariat daerah : Pekanbaru

Republik Indonesia. (2003). Undang-Undang No. 20/2003 Tentang Sistem Pendidikan Nasional. Sekretariat Negara : Jakarta

Riedel S., et al. (2019). Medical Microbiology. 28th ed. New York: McGrawHill Education/Medical.

Sarafino, E. P., \& Smith, T. (2011). Health Psychology: Biopsychosocial Interactions (7th.ed). United States of America: John Wiley \& Sons, Ltd.

Shang W, Yang Y, Rao Y, Rao X. (2020). The outbreak of SARS-CoV-2 pneumonia calls for viral vaccines. NPJ Vaccines. 5(18).

Susilo, A., et.al. (2020) Coronavirus Disease 2019: Tinjauan Literatur Terkini. Jurnal penyakit dalam indonesia, 7(1), 45-67

Syafrida., \& Hartati,R. (2020). Bersama melawan virus covid 19 di Indonesia. SALAM : jurnal social \& budaya syar'I, 7(6), 495-508, DOI: 10.15408/sjsbs.v7i6.15325

Wibawa, S. (2017). Tridharma Perguruan Tinggi (Pendidikan Dan Pengabdian Kepada Masyarakat). Disampaikan dalam Rapat Perencanaan Pengawasan Proses Bisnis Perguruan Tinggi Negeri. Yogyakarta, 29, 01-15.

World Health Organization. (2020) Coronavirus disease (COVID-19) advice for the public [Internet]. Available from: https://www.who.int/emergencies/diseases/novelcoronavirus-2019/advice-for-public.

World Health Organization. (2020). Clinical management of severe acute respiratory infection when novel coronavirus (nCoV) infection is suspected. Geneva: World Health Organization. 
World Health Organization. (2020). Critical preparedness, readiness and response actions for COVID-19. Geneva: World Health Organization

World Health Organization. (2020). Infection prevention and control during health care when novel coronavirus (nCoV) infection is suspected. Geneva: World Health Organization 